\title{
cAMP Response Element-Binding Protein Deficiency Allows for Increased Neurogenesis and a Rapid Onset of Antidepressant Response
}

\author{
Tamar L. Gur, ${ }^{1}$ Alana C. Conti, ${ }^{1}$ Jessica Holden, ${ }^{1}$ Anita J. Bechtholt, ${ }^{2}$ Tiffany E. Hill, ${ }^{2}$ Irwin Lucki, ${ }^{1,2}$ Jessica E. Malberg, ${ }^{3}$ \\ and Julie A. Blendy ${ }^{1}$ \\ Departments of ${ }^{1}$ Pharmacology and ${ }^{2}$ Psychiatry, University of Pennsylvania School of Medicine, Philadelphia, Pennsylvania 19104, and ${ }^{3}$ Neuroscience \\ Discovery, Wyeth Research, Princeton, New Jersey 08852
}

cAMP response element-binding protein (CREB) has been implicated in the molecular and cellular mechanisms of chronic antidepressant (AD) treatment, although its role in the behavioral response is unclear. CREB-deficient (CREB ${ }^{\alpha \Delta}$ mutant) mice demonstrate an antidepressant phenotype in the tail suspension test (TST) and forced-swim test. Here, we show that, at baseline, $\mathrm{CREB}^{\alpha \Delta}$ mutant mice exhibited increased hippocampal cell proliferation and neurogenesis compared with wild-type (WT) controls, effects similar to those observed in WT mice after chronic desipramine (DMI) administration. Neurogenesis was not further augmented by chronic DMI treatment in $\mathrm{CREB}^{\alpha \Delta}$ mutant mice. Serotonin depletion decreased neurogenesis in $\mathrm{CREB}^{\alpha \Delta}$ mutant mice to WT levels, which correlated with a reversal of the antidepressant phenotype in the TST. This effect was specific for the reversal of the antidepressant phenotype in these mice, because serotonin depletion did not alter a baseline anxiety-like behavior in CREB $^{\alpha \Delta}$ mutant mice. The response to chronic AD treatment in the novelty-induced hypophagia $(\mathrm{NIH})$ test may rely on neurogenesis. Therefore, we used this paradigm to evaluate chronic $\mathrm{AD}$ treatment in $\mathrm{CREB}^{\alpha \Delta}$ mutant mice to determine whether the increased neurogenesis in these mice alters their response in the NIH paradigm. Whereas both WT and $\mathrm{CREB}^{\alpha \Delta}$ mutant mice responded to chronic AD treatment in the NIH paradigm, only CREB ${ }^{\alpha \Delta}$ mutant mice responded to acute AD treatment. However, in the elevated zero maze, DMI did not reverse anxiety behavior in mutant mice. Together, these data show that increased hippocampal neurogenesis allows for an antidepressant phenotype as well as a rapid onset of behavioral responses to $\mathrm{AD}$ treatment.

Key words: novelty-induced hypophagia; NIH; CREB; neurogenesis; DMI; mouse; depression

\section{Introduction}

Antidepressant (AD) treatment involves amelioration of symptoms over the course of weeks or months (Wong and Licinio, 2001). Chronic exposure to AD is accompanied by transcriptional and cellular modulation, occurring on a later timescale than changes in monoamine levels and consistent with the onset of the relief of symptoms (Frazer and Benmansour, 2002; Nestler et al., 2002; Young et al., 2002; Carlezon et al., 2005; Blendy, 2006). In particular, the transcription factor cAMP response element-binding protein (CREB) is upregulated after chronic AD treatment; increases in CREB mRNA and protein, or phosphorylation of CREB have been shown in the hippocampus after

\footnotetext{
Received Dec. 8, 2006; revised June 12, 2007; accepted June 18, 2007.

This work was supported by National Institute of Mental Health Grants U01MH0723832 and T32-MH14654 and by the National Cooperative Drug Discovery Group for the Treatment of Mood Disorders. We thank Jessica Cleck for experimental assistance and Dr. Cedric Mombereau for critical reading of this manuscript.

Correspondence should be addressed to Dr. Julie A. Blendy, Department of Pharmacology, Center for Neurobiology and Behavior, Translational Research Laboratories, 125 South 31st Street, Philadelphia, PA 19104-3403. E-mail: blendy@mail.med.upenn.edu.

A. C. Conti's present address: Department of Pediatrics, Washington University, St. Louis, M0 63110.

J. Holden's present address: Technical Resources International, Bethesda, MD 20817.

J. E. Malberg's present address: Psychogenics, Inc., Tarrytown, NY 10591.

D0I:10.1523/JNEUROSCI.2051-07.2007

Copyright $\odot 2007$ Society for Neuroscience $\quad$ 0270-6474/07/277860-09\$15.00/0
}

chronic, but not acute AD administration (Nibuya et al., 1996; Thome et al., 2000; Blom et al., 2002; Tiraboschi et al., 2004).

The significance of CREB regulation in mechanisms through which chronic $\mathrm{AD}$ treatment produces symptomatic relief is unknown. Hippocampal atrophy is hypothesized to be one contributing factor to the affective and cognitive impairments observed in depression (Watanabe et al., 1992; Stein-Behrens et al., 1994; Magarinos et al., 1996; Sheline, 1996; McEwen, 1999; Sheline et al., 2003). AD drugs that increase neurogenesis in the dentate gyrus of the adult hippocampus plausibly counteract this pathology of depression (Malberg et al., 2000; Czeh et al., 2001; Manev et al., 2001; Santarelli et al., 2003; Kodama et al., 2004; Sairanen et al., 2005). CREB appears to play a role in neurogenesis, because immature neurons in the adult hippocampus express phosphorylated CREB (Nakagawa et al., 2002b). Furthermore, transgenic mice expressing a dominant-negative CREB mutation in the hippocampus demonstrated a reduction in neurogenesis (Nakagawa et al., 2002a). The concurrent increases of both CREB and neurogenesis in the hippocampus in response to chronic $\mathrm{AD}$ treatment suggest that CREB may regulate hippocampal neurogenesis.

Although CREB may mediate molecular and cellular changes induced by $\mathrm{AD}$ treatment, its role in modulating behavioral responses to chronic treatment is still unclear. We previously 
reported that mice deficient in CREB (CREB ${ }^{\alpha \Delta}$ mutant) (Hummler et al., 1994; Blendy et al., 1996) show a baseline decrease in immobility in the forced-swim test (FST) and tail suspension test (TST), behavioral models commonly used to evaluate AD efficacy (Lucki, 2001; Cryan et al., 2005). However, immobility is further decreased with AD treatment (Conti et al., 2002), suggesting that this acute behavioral response is mediated by a CREB-independent mechanism. We examined neurogenesis in these animals and showed that $\mathrm{CREB}^{\alpha \Delta}$ mutant mice had increased levels of hippocampal neurogenesis at baseline. Reductions in neurogenesis achieved by serotonin depletion in mutant animals correlated with a reversal in the baseline antidepressant phenotype of $\mathrm{CREB}^{\alpha \Delta}$ mutant mice in the TST, whereas wildtype (WT) mice did not show a change in either parameter. The novelty-induced hypophagia (NIH) and novelty suppressed feeding (NSF) paradigms are two closely related paradigms that are responsive to chronic antidepressant treatment, and this behavioral response has been correlated with neurogenesis. In these paradigms, latency to consume food in a novel environment is measured and chronic but not acute AD treatment, as well as acute benzodiazepine treatment, reduces the latency to feed in a novel environment (Merali et al., 2003; Dulawa and Hen, 2005). This effect of chronic antidepressant treatment, however, is diminished when neurogenesis is impaired (Santarelli et al., 2003). This result suggests that the increase in neurogenesis associated with chronic antidepressant treatment is required for the behavior associated with this paradigm. Therefore, we examined the effect of chronic DMI administration using the NIH paradigm. We found that, whereas both WT and $\mathrm{CREB}^{\alpha \Delta}$ mutant mice responded to chronic $\mathrm{AD}$ treatment in this paradigm, only $\mathrm{CREB}^{\alpha \Delta}$ mutant mice responded to acute treatment. Together, these findings suggest that, in the absence of CREB throughout development, an antidepressant phenotype emerges on both a cellular and behavioral level.

\section{Materials and Methods}

Animals. CREB ${ }^{\alpha \Delta}$ mutant mice were backcrossed to the inbred mouse strains $129 \mathrm{SvEv}$ and $\mathrm{C} 57 \mathrm{BL} / 6$ for $>20$ generations. For these experiments, WT and CREB ${ }^{\alpha \Delta}$ mutants were $\mathrm{F}_{1}$ hybrids obtained from crossing mice heterozygous for the CREB mutation from each strain. Mice (3-6 months of age; $20-40 \mathrm{~g}$ ) were group housed and maintained on a $12 \mathrm{~h}$ light/dark cycle with food and water available ad libitum in accordance with the University of Pennsylvania Animal Care and Use Committee. For the NIH paradigm, mice were housed in groups of two. All experimental testing sessions were conducted between 9:00 A.M. and 3:00 P.M., with animals randomly assigned to treatment conditions and tested in counterbalanced order.

Drugs. $p$-Chlorophenylalanine methyl ester hydrochloride (PCPA), a tryptophan hydroxylase inhibitor $(250 \mathrm{mg} / \mathrm{kg}$, i.p.) (Sigma, St. Louis, MO) was dissolved in deionized water and injected twice daily for $3 \mathrm{~d}$. The last dose was administered $18 \mathrm{~h}$ before behavioral testing or killing for neurogenesis. Desipramine (DMI) $(12.5 \mathrm{mg} / \mathrm{kg}$ ) (Sigma) was prepared immediately before use and injected intraperitoneally using a volume of $10 \mathrm{ml} / \mathrm{kg}$. The dose was calculated as milligrams per kilogram of the salt form and was dissolved in $0.9 \%$ saline. For acute treatment, mice were injected with DMI or $0.9 \%$ saline in the morning and afternoon of the day before, and morning of the day of testing, for a total of three doses before exposure to the zero maze or NIH paradigm. For chronic treatment, mice were treated with DMI or saline twice daily for 3 weeks.

Tail suspension test. Eighteen hours after the final injection of saline or PCPA, mice were individually suspended by the tail to a horizontal ringstand bar (distance from floor, $35 \mathrm{~cm}$ ) using adhesive tape affixed $2 \mathrm{~cm}$ from the tip of the tail. Mice demonstrated several escape-oriented behaviors interspersed with bouts of immobility as the session progressed. A 6 min test session was videotaped and scored by a trained observer who was blind to the experimental conditions. The behavioral measure scored was the duration of "immobility," defined as the time when mice were judged to cease escape-motivated behaviors.

Elevated zero maze. The zero maze (Stoelting, Wood Dale, IL) was elevated 24 inches from the ground and consisted of two open areas (wall height, 0.5 inches) and two closed areas (wall height, 12 inches). Each mouse was placed in the closed area and the duration of testing was $300 \mathrm{~s}$. The Viewpoint Tracking System (Viewpoint, Champagne au Mont d'Or, France) was used to video record and register the time spent in the open areas and the number of entries into each area. Ethological parameters [rearing, stretch-attend-posture (SAP), and head-dips] were scored manually. The test was performed in dim lighting. Mice were acclimated to the room for $1 \mathrm{~h}$ before testing. For the PCPA experiment, mice received the final dose of PCPA $18 \mathrm{~h}$ before testing. For the DMI experiment, mice received a total of three doses of DMI before testing (9:00 A.M. and 5:00 P.M. of the day before testing, and 9:00 A.M. on test day) $1-4 \mathrm{~h}$ before testing.

Novelty-induced hypophagia. For 1 week before the training period, and for the duration of the experiment, mice were housed in groups of two. Training consisted of daily sessions in which mice were exposed to a highly palatable food (peanut butter chips; Nestle, Glendale, CA) in a clear plastic dish. Plastic dividers were placed inside each cage to separate the mice during the training and home cage testing periods. Mice were acclimated for $1 \mathrm{~h}$ before placement of food. Food was placed in the cage for $15 \mathrm{~min}$ and latency to consume was measured. By the 12th day, a baseline latency to approach the food dish was reached such that there was $<20 \%$ variability between mice. For chronic antidepressant treatment, mice were injected for $25 \mathrm{~d}$ with $12.5 \mathrm{mg} / \mathrm{kg}$ DMI or $0.9 \%$ saline in the morning (9:00-10:00 A.M.) and afternoon (4:00-5:00 P.M.). Testing in the home, novel environment, and home environment occurred on the last $3 \mathrm{~d}$ of injections.

For testing in the novel environment, mice were removed from the home cage and placed in an empty standard cage with no bedding, which was sprayed with a cleaner (Pine Sol) to emit a novel odor and was placed in a white box with bright light illumination. Latency to consume was recorded. These mice were tested 3-6 h after DMI injection. Mice were tested again in the home cage on the day after novel testing (Home 2), under the same conditions as the first home test day (Home 1). In the acute treatment experiment, training was performed as described above. Mice were injected on the three testing days with $12.5 \mathrm{mg} / \mathrm{kg}$ DMI or saline in the morning (9:00-10:00 A.M.) and afternoon (4:00-5:00 P.M.) and testing occurred 3-6 h after the morning injection of DMI. Thus, a total of three doses of DMI were administered before exposure to the novel environment.

Bromodeoxyuridine injections and tissue preparation. For evaluation of the effect of DMI on short-term cell survival and bromodeoxyuridine (BrdU) labeling, animals were administered saline or DMI $(12.5 \mathrm{mg} / \mathrm{kg}$, i.p.; Sigma) twice daily for $38 \mathrm{~d}$. Twenty-four hours after the last DMI or saline injection, mice were administered BrdU twice daily $(50 \mathrm{mg} / \mathrm{kg}$, i.p.; Zymed, San Francisco, CA) for 4 d. Twenty-four hours after the last BrdU injection, mice were anesthetized and transcardially perfused $(0.1 \mathrm{M}$ cold PBS for $5 \mathrm{~min}$ followed by $4 \%$ cold paraformaldehyde for $15 \mathrm{~min}$ ). A second set of animals were allowed to survive for 6 weeks after the BrdU injection, at which time they were anesthetized and perfused for evaluation of long-term cell survival and phenotypic labeling. To determine the effect of PCPA depletion on cell proliferation in $\mathrm{CREB}^{\alpha \Delta}$ mutant and WT littermates, mice were perfused $2 \mathrm{~h}$ after a single BrdU injection (100 $\mathrm{mg} / \mathrm{kg}$ ). All brains were postfixed overnight in paraformaldehyde at $4^{\circ} \mathrm{C}$ and stored at $4^{\circ} \mathrm{C}$ in $30 \%$ sucrose. Serial sections of the brains were cut (35 $\mu \mathrm{m}$ sections) through the entire hippocampus using a cryostat, and sections were stored in $0.1 \% \mathrm{NaN}_{3} / \mathrm{PBS}$. This BrdU-labeling paradigm has been successfully used in multiple laboratories to accurately quantify labeled cells. In addition, the use of confocal microscopy with BrdU and neuronal and glial markers allows for additional evaluation of neurogenesis.

Immunohistochemistry. Free-floating sections were used in the determination of BrdU labeling. Series of every ninth section through the hippocampus or subventricular zone of the lateral ventricle were processed for BrdU immunohistochemistry $(\sim 10-12$ sections per brain). 
Using this spacing ensures that the same BrdU-positive cell will not be counted twice. Sections evaluated for proliferation and neurogenesis were heated for $20 \mathrm{~min}$ at $75^{\circ} \mathrm{C}$ in $0.01 \mathrm{M}$ citric acid, $\mathrm{pH} 6.0$, for antigen retrieval. After washing in $0.1 \mathrm{M}$ PBS, sections were permeabilized in $0.1 \%$ trypsin with $0.1 \% \mathrm{CaCl}_{2}$ for $10 \mathrm{~min}$ at room temperature. Sections were rinsed with $0.1 \mathrm{M}$ PBS and denatured with $2 \mathrm{~N} \mathrm{HCl}$ for $30 \mathrm{~min}$ at room temperature. After blocking with 3\% normal goat serum for $60 \mathrm{~min}$ at room temperature, sections were incubated with anti-mouse BrdU (1: 150; Becton Dickinson, Franklin Lakes, NJ) with 0.5\% Tween 20 overnight at room temperature. Sections were then incubated for $60 \mathrm{~min}$ with secondary antibody (1:200 biotinylated goat anti-mouse IgG; Sigma) followed by quenching of endogenous peroxidases with 3\% hydrogen peroxide for $15 \mathrm{~min}$ at room temperature. Secondary antibody signal was amplified using an avidin-biotin complex (Vector Laboratories, Burlingame, CA) and visualized with DAB (Vector Laboratories).

For analysis of mature cell phenotypes, free-floating sections were incubated in $2 \mathrm{~N} \mathrm{HCl}$ at $40^{\circ} \mathrm{C}$ for $20 \mathrm{~min}$. Sections were rinsed in $0.02 \mathrm{M}$ potassium PBS (KPBS) and incubated with $0.3 \%$ Triton X-100 and 5\% normal goat serum in $0.02 \mathrm{M}$ KPBS. Slices were incubated in primary antibodies for $3 \mathrm{~d}$ at $4^{\circ} \mathrm{C}$ [1:100 anti-rat BrdU (Immunologicals Direct, Raleigh, NC); 1:100 anti-mouse neuronal nuclei (NeuN) (Millipore, Temecula, CA); and 1:2500 rabbit anti-S100 $\beta$ (Swant, Bellinzona, Switzerland)]. After rinsing in KPBS, a 1:200 dilution of secondary antibodies Alexa 488 anti-rat IgG (in goat), Alexa 633 anti-rabbit IgG (in goat), and Alexa 568 anti-mouse IgG (in goat; highly cross absorbed) was applied for $2 \mathrm{~h}$ at room temperature (Invitrogen, Eugene, OR). After washing, sections were slide-mounted with ProLong antifade solution (Invitrogen) and stored under dark conditions at $4^{\circ} \mathrm{C}$.

Immunohistochemical quantitation. All BrdU-labeled cells in the dentate gyrus (granule cell layer) were counted in each section by an experimenter blinded to the study code. To distinguish single cells within clusters, all counts were performed at 40 and $100 \times$ under a light microscope, omitting cells in the outermost focal plane. For the short-term survival and proliferation cell counts ( $n=6-8$ per group), a cell was counted as being in the subgranular zone (SGZ) of the dentate gyrus if it was touching, or within the SGZ. Cells that were located more than two cells away from the SGZ were classified as hilar. For long-term survival cell counts ( $n=6-8$ per group), all BrdU-positive cells that were located within the granule layer of the dentate gyrus were scored. Cells that were located more than two cells away from the granule layer were considered hilar. The total number of BrdU-labeled cells per section was determined and multiplied by 9 to obtain the total number of cells per dentate gyrus. For phenotypic analysis $(n=6$ per group), triple-labeled slices (BrdU, NeuN, S100 $\beta$ ) were analyzed using a Leica (Bannockburn, IL) TCS-NT confocal microscope, and images were captured using Leica confocal software. At least $50 \mathrm{BrdU}$-positive cells per animal were further analyzed using $z$-plane sectioning in $1 \mu \mathrm{m}$ steps to confirm the colocalization of both BrdU and either of the markers NeuN or S100 $\beta$. Cells were analyzed in the $x y z$-plane using Imaris Software (Bitplane, Zurich, Switzerland).

Analysis of serotonin tissue content. Eighteen hours after the last injection of PCPA, mice were killed. Brains were rapidly microdissected, and tissues were flash frozen in liquid nitrogen and stored at $-80^{\circ} \mathrm{C}$ until analysis. Individual brain regions were homogenized in a $100 \mu \mathrm{M}$ ethylenediamine tetra-acetic acid solution dissolved in $0.1 \mathrm{~N}$ perchloric acid ( $15 \mu \mathrm{l} / \mathrm{mg}$ of tissue). Samples were centrifuged at $2-8^{\circ} \mathrm{C}$ for $15 \mathrm{~min}$ at $15,000 \mathrm{rpm}$ and supernatant was filtered using $0.45 \mu \mathrm{m}$ nylon Costar (Cambridge, MA) Spin-X centrifuge filters. HPLC coupled with electrochemical detection (EC) was used to assay the filtered supernatant for serotonin content.

The HPLC-EC system (Bioanalytical Systems, West Lafayette, IN) consisted of a PM-80 pump, a Sample Sentinel autosampler, and a LC-4C electrochemical detector. Twelve microliters of sample were injected and pumped through a reverse-phase microbore column (ODS; $3 \mu \mathrm{m} ; 1 \times$ $100 \mathrm{~mm}$; Bioanalytical Systems) at a flow rate of $0.6 \mathrm{ml} / \mathrm{min}$ with electrodetection at $+0.6 \mathrm{~V}$. Separation for serotonin was accomplished by using an HPLC mobile phase consisting of $90 \mathrm{~mm}$ sodium acetate, $35 \mathrm{~mm}$ citric acid, 0.34 mм EDTA, $1.2 \mathrm{~mm}$ sodium octyl sulfate, and $9 \%$ methanol $(\mathrm{v} / \mathrm{v})$ with the addition of $2 \%$ dimethlyacetamide $(\mathrm{v} / \mathrm{v}) . \mathrm{HCl}(12 \mathrm{~N})$ was used to adjust the $\mathrm{pH}$ of the mobile phase to 4.2 .
Statistics. For the BrdU immunohistochemistry, ANOVA and Fisher post hoc tests were performed to establish statistical significance. For the PCPA/neurogenesis experiment, we applied a mixed-model analysis (SAS Linux, version 9; Proc Mixed) with genetic group as a betweengroup factor and saline versus PCPA as a within-group factor. A post hoc mixed-model contrast analysis was performed to test the hypothesis that the $\mathrm{CREB}^{\alpha \Delta}$ mutant mice show increased neurogenesis in comparison with other groups, comparing the saline-treated $\mathrm{CREB}^{\alpha \Delta}$ mutant mice with all other groups. For the TST, we applied a mixed-model analysis with genetic group as a between-group factor and saline versus DMI as a within-group factor. A post hoc mixed-model contrast analysis was performed, comparing the saline-treated $\mathrm{CREB}^{\alpha \Delta}$ mutant mice with all other groups, to test the hypothesis that the $\mathrm{CREB}^{\alpha \Delta}$ mutant mice showed decreased immobility in comparison with other groups. For the zero maze experiments, the ANOVA was performed on two genetic groups (CREB ${ }^{\alpha \Delta}$, WT) by two treatment groups (SAL, DRUG), with time in the open arm as a dependent variable. For the NIH paradigm experiments, latency served as a dependent variable in a two genetic groups $\left(\mathrm{CREB}^{\alpha \Delta}\right.$, WT) by two treatment groups (SAL, DMI) ANOVA, with condition (Home 1, Novel, Home 2) as a repeated-measures (within) factor. The analysis was implemented in SAS (Linux, version 9; Proc GLM).

\section{Results}

\section{The antidepressant phenotype is associated with increased} cell proliferation in CREB-deficient mice

Chronic antidepressant treatment has been shown to increase hippocampal neurogenesis. $\mathrm{CREB}^{\alpha \Delta}$ mutant mice demonstrate antidepressant-like responses in tests such as the FST and TST, which are readouts of antidepressant efficacy. To determine whether altered neurogenesis may underlie the antidepressant phenotype, we examined granule cell proliferation and neurogenesis in wild-type and $\mathrm{CREB}^{\alpha \Delta}$ mutant mice.

Animals were administered BrdU, and after different time points of killing, the number of BrdU-positive cells in the adult dentate gyrus was determined using immunohistochemical detection.

At the $4 \mathrm{~d}$ time point, $\mathrm{CREB}^{\alpha \Delta}$ mutant mice exhibited significantly more BrdU-positive cells than respective WT controls $\left(F_{(1,23)}=5.24 ; p=0.0316\right)$, corresponding to a $52 \%$ increase (Fig. 1A). In addition, chronic DMI treatment (5 weeks; 12.5 $\mathrm{mg} / \mathrm{kg}$, twice daily, i.p) was also examined. WT mice demonstrate a significantly increased number of BrdU-positive cells in DMI treated compared with saline controls by $51 \%\left(F_{(1,23)}=4.73 ; p=\right.$ $0.0402)$. However, DMI treatment did not further increase the number of BrdU-positive cells in $\mathrm{CREB}^{\alpha \Delta}$ mutant mice compared with saline-treated mutant controls. The number of BrdUpositive cells in saline-treated CREB-deficient mice was comparable with that of DMI-treated WT mice.

\section{The antidepressant phenotype is associated with increased neurogenesis in CREB-deficient mice}

To determine whether the newly born cells observed in WT and CREB-deficient mice survive and differentiate into neurons, cells labeled with BrdU were allowed to mature for 6 weeks. Salinetreated $\mathrm{CREB}^{\alpha \Delta}$ mutant mice exhibited significantly increased numbers of BrdU-positive cells in the granule cell layer compared with WT controls $\left(F_{(1,24)}=12.49 ; p=0.0017\right)$ (Fig. $\left.1 B\right)$, suggesting that the many of the newly born cells survived for at least 6 weeks. In a similar manner, in WT mice, DMI treatment significantly increased the number of BrdU-positive cells compared with saline-treated WT controls $\left(F_{(1,24)}=5.098 ; p=0.0033\right)$ (Fig. $1 B$ ) at this 6 week time point. However, in $\mathrm{CREB}^{\alpha \Delta}$ mutant mice, DMI had no additional effect on the number of 


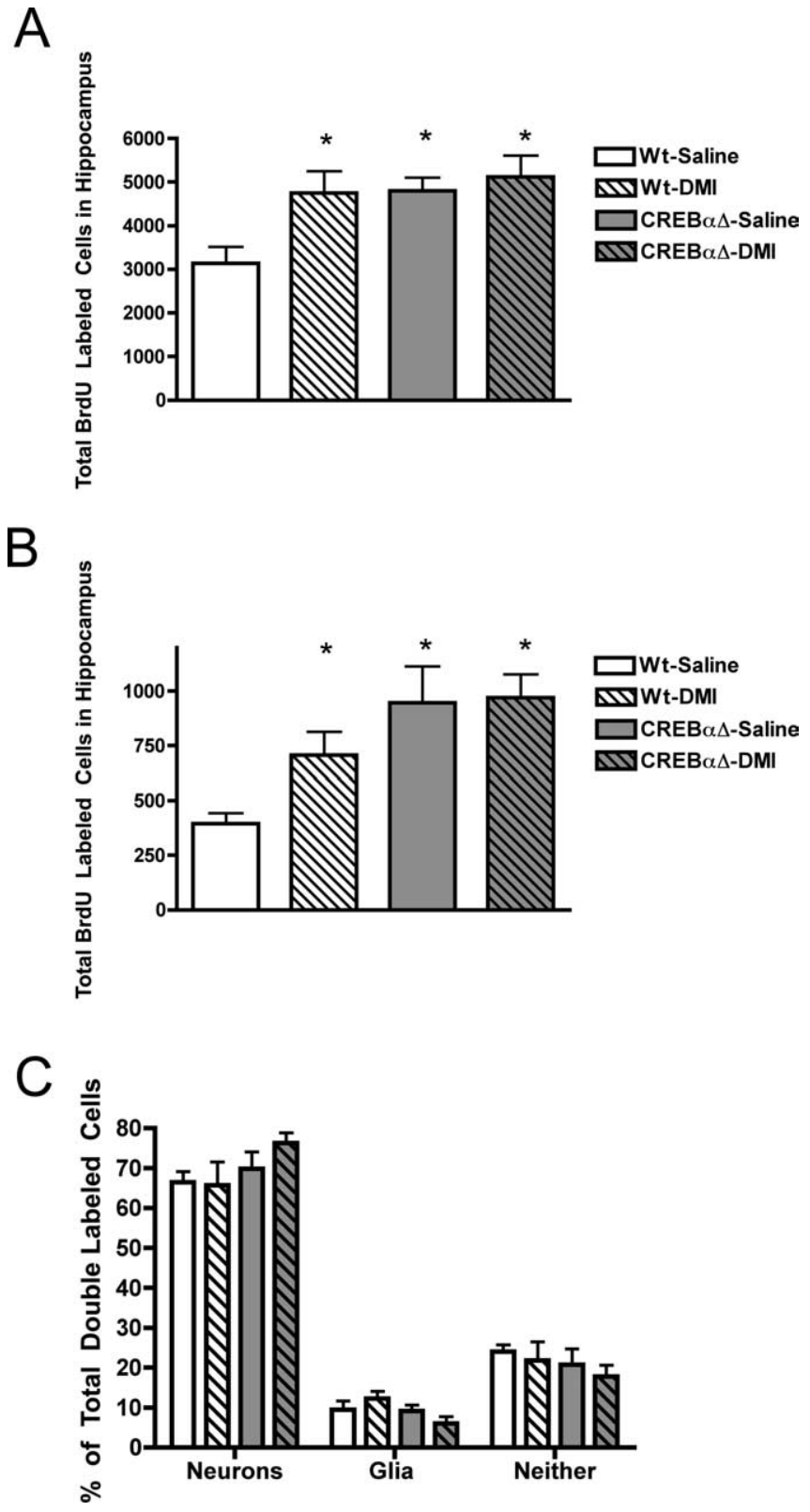

Figure 1. $\quad A-C$, CREB deficiency increases the number of BrdU-positive cells at $4 \mathrm{~d}(\boldsymbol{A})$ and 6 weeks $(\boldsymbol{B})$ in the dentate gyrus, with the majority of BrdU-positive cells differentiating into neurons (C). Saline-treated CREB ${ }^{\alpha \Delta}$ mutant mice demonstrated significantly increased number of BrdU-positive cells compared with WT controls ( ${ }^{*} p<0.05 ; n=6-8$ ). This increase was maintained at the 6 week time point, at which the majority of the BrdU-positive cells matured into neurons, indicating a net increase in neurogenesis in the CREB ${ }^{\alpha \Delta}$ mutant mice. Chronic DMI treatment significantly increased BrdU labeling in the dentate gyrus of WT mice at both time points. The majority of the surviving cells matured into neurons, indicating a DMI-induced increase in neurogenesis in WT mice. In contrast to the DMI-induced increase in neurogenesis seen in WT mice, the CREB ${ }^{\alpha \Delta}$ mutant mice show no additional changes in BrdU labeling or neurogenesis. Saline-treated CREB ${ }^{\alpha \Delta}$ mutant mice demonstrated comparable numbers of BrdU-positive cells and neurogenesis with that of DMI-treated WT controls $\left({ }^{*} p<0.05 ; n=\right.$ $6-9)$. In all groups, the majority of surviving BrdU-positive cells expressed the neuronal marker, NeuN. DMI treatment had no effect on the phenotypic distribution of surviving BrdU-positive cells in WT or CREB ${ }^{\alpha \Delta}$ mutant mice. Error bars indicate SEM.

BrdU-positive cells. Similar to previous reports, the total number of BrdU-positive cells after 6 weeks was lower compared with that at $24 \mathrm{~h}$ (Gould et al., 1999; Malberg et al., 2000; Nakagawa et al., 2002a).

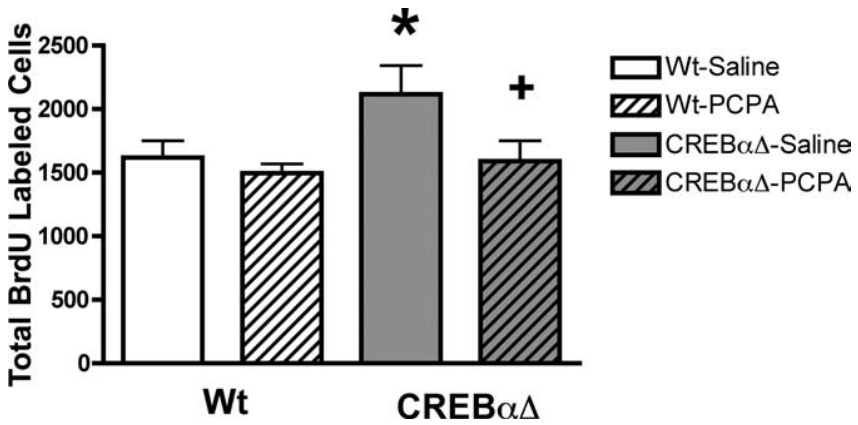

Figure 2. Serotonin depletion reduced proliferation in CREB ${ }^{\alpha \Delta}$ mutant mice to WT levels. CREB ${ }^{\alpha \Delta}$ mutant mice show a significant increase in cell proliferation compared with WT mice ( $p=0.0494)$. Treatment with PCPA $(250 \mathrm{mg} / \mathrm{kg})$ twice a day for $3 \mathrm{~d}$ reverses this increase in cell proliferation in CREB ${ }^{\alpha \Delta}$ mutant mice to WT levels $(p=0.0340)$, whereas PCPA treatment had no effect on cell proliferation in WT mice $(N=5-6)$. Error bars indicate SEM. ${ }^{*} p<0.05 ;{ }^{\dagger} p<0.05$.

\section{Phenotypic analysis of neurogenesis}

To determine whether the BrdU-positive cells at the 6 week time point have matured into neurons or glia, triple labeling with BrdU, NeuN (marker for mature neurons), and S100 $\beta$ (glial marker) was performed (Fig. $1 C$; supplemental Fig. 1, available at www.jneurosci.org as supplemental material). Confocal microscopic analysis with $z$-plane sectioning confirmed that the majority of surviving BrdU-positive cells matured into neurons in all groups. Phenotypic analysis revealed that $67 \pm 3 \%$ of the surviving BrdU-labeled cells in saline-treated WT mice expressed the neuronal marker, NeuN. After DMI treatment, $66 \pm 6 \%$ of surviving BrdU-labeled cells exhibited a neuronal phenotype. $\mathrm{CREB}^{\alpha \Delta}$ mutant mice demonstrated similar patterns of neuronal differentiation, with $70 \pm 4 \%$ of surviving BrdU-positive cells maturing into neurons in saline controls, compared with $76 \pm$ $3 \%$ after DMI treatment. Fewer BrdU-labeled cells differentiated into glial cells (Fig. 1C). In WT mice, saline controls demonstrated $10 \pm 2 \%$ of BrdU-positive cells with glial phenotypes as did $12 \pm 2 \%$ after DMI treatment. In saline-treated CREBdeficient mice, $9 \pm 2 \%$ of BrdU-labeled cells expressed glial markers, compared with $6 \pm 2 \%$ after DMI treatment. The remaining $18-24 \%$ of BrdU-labeled cells were not labeled with either NeuN or $\mathrm{S} 100 \beta$, indicating a population of quiescent, undifferentiated cells, or an existing cell type not labeled with the antibodies used (Fig. 1C). BrdU, however, is not without its caveats (Eisch, 2002). BrdU may be taken up not only by proliferating cells but also by cells undergoing repair. Although we cannot rule out this possibility, it has been reported that this low level of DNA incorporation is not easily detected using immunohistochemical methods (Palmer et al., 2000).

Together, these data indicate that CREB deficiency produces an increase in BrdU-positive cells that survive for 6 weeks, and the majority of those mature cells are neurons, indicating a net increase in neurogenesis.

\section{Serotonin depletion decreased cell proliferation in CREB-} deficient mice to WT levels

To examine the role of CREB deficiency and serotonin depletion on cell proliferation, mice were treated with saline or PCPA, a specific inhibitor of tryptophan hydroxylase, and killed $2 \mathrm{~h}$ after the BrdU injection. This $2 \mathrm{~h}$ time point was chosen because it represents one cell cycle of labeling (Cameron and McKay, 2001) and is thought to be an accurate measure of cell proliferation (Malberg et al., 2000). As shown in Figure 2, CREB ${ }^{\alpha \Delta}$ mutant 


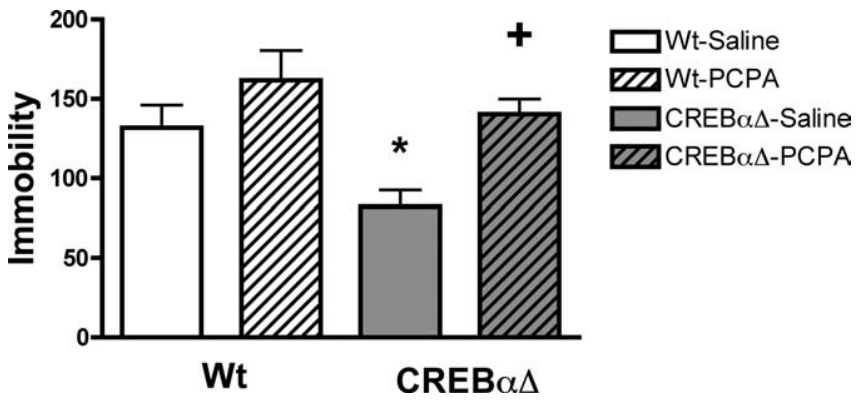

Figure 3. Serotonin depletion reversed the antidepressant phenotype of CREB ${ }^{\alpha \Delta}$ mutant mice in the TST. Mice were treated with PCPA twice a day for $3 \mathrm{~d}$. Immobility in the TST was measured $18 \mathrm{~h}$ after the last injection. The TST revealed a significant effect of genotype and treatment, with the PCPA-treated CREB ${ }^{\alpha \Delta}$ mutant mice returning to WT levels $(n=4-8)$. Error bars indicate SEM. ${ }^{*} p<0.05 ;{ }^{\dagger} p<0.05$.

mice show an increase in BrdU-labeled cells. PCPA treatment led to a reversal of this increase in $\mathrm{CREB}^{\alpha \Delta}$ mutant mice, whereas PCPA had no significant effect on WT mice. A mixed model statistical analysis found main effects for genetic group, $\left(F_{(1,22)}=\right.$ $4.35 ; p=0.0494)$ and for treatment, $\left(F_{(1,22)}=5.14 ; p=0.0340\right)$. Post hoc contrast analysis revealed that the hypothesized $\left(\mathrm{CREB}^{\alpha \Delta}\right.$ saline) group had significantly increased values compared with all other groups, $\left(F_{(1,23)}=10.54 ; p=0.0036\right)$. These data indicate that CREB deletion increases cell proliferation, which can then be decreased to WT levels by serotonin depletion.

\section{Serotonin depletion increased immobility times of CREB- deficient mice to WT levels}

To determine whether reversing the baseline increase in neurogenesis would have a functional behavioral correlate in the TST, we administered PCPA to WT and $\mathrm{CREB}^{\alpha \Delta}$ mutant mice and measured the effect on immobility. Mixed-model analysis found main effects for genetic group $\left(F_{(1,22)}=6.18 ; p=0.0210\right)$ and for treatment, $\left(F_{(1,22)}=9.51 ; p=0.0054\right)$. As shown in Figure 3, $\mathrm{CREB}^{\alpha \Delta}$ mutant mice had significantly reduced values compared with all other groups $\left(F_{(1,24)}=10.10 ; p=0.0041\right)$. This increase demonstrates that the relationship between neurogenesis and behavior in these mice is maintained after serotonin depletion and supports a causal relationship between neurogenesis and behavior in these mice.

\section{Serotonin depletion has no effect on anxiety in the elevated zero maze}

In addition to an antidepressant phenotype, $\mathrm{CREB}^{\alpha \Delta}$ mutant mice also exhibit increased baseline anxiety (Graves et al., 2002; Hebda-Bauer et al., 2004). To determine whether the reversal of neurogenesis and the antidepressant phenotype is accompanied by a decrease in anxiety, we evaluated mice in the elevated zero maze after serotonin depletion. As shown in Figure 4, treatment with PCPA did not have an effect on time spent in the open arm in either WT or $\mathrm{CREB}^{\alpha \Delta}$ mutant mice $\left(F_{(1,30)}=0.06 ; p>0.05\right)$, with the latter once again demonstrating a baseline increase in anxiety $\left(F_{(1,30)}=6.76 ; p=0.0143\right)$.

\section{Serotonin levels are equivalent in WT and CREB ${ }^{\alpha \Delta}$ mutant mice}

A possible explanation for the phenotype observed in $\mathrm{CREB}^{\alpha \Delta}$ mutant mice would be that the animals have altered serotonin levels. Therefore, we measured tissue serotonin content in these animals. Two-way ANOVAs demonstrate that the baseline serotonin level in $\mathrm{CREB}^{\alpha \Delta}$ mutant mice did not differ from that of

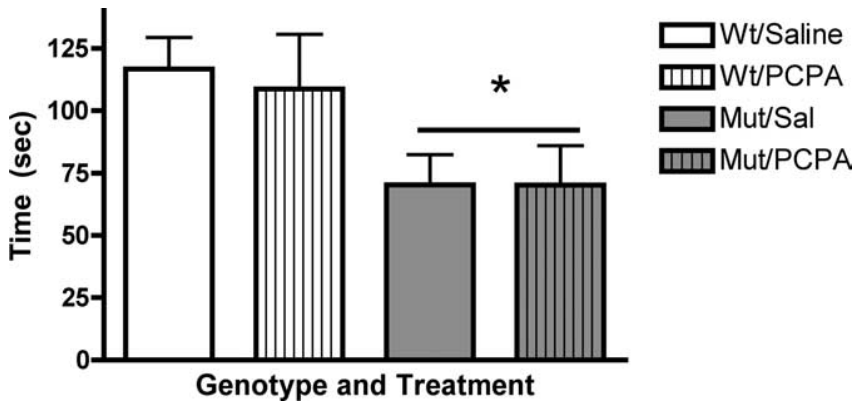

Figure 4. Serotonin depletion does not have an effect on anxiety in the elevated zero maze. Mice were treated with PCPA and tested in the elevated zero maze $18 \mathrm{~h}$ after the last dose. $\mathrm{CREB}^{\alpha \Delta}$ mutant mice spent significantly less time in the open arm of the maze, reflecting a proanxiety phenotype. Treatment with PCPA did not alter anxiety levels in either WT or CREB ${ }^{\alpha \Delta}$ mutant mice $(n=8-9)$. Error bars indicate SEM. ${ }^{*} p<0.05$.

WT mice throughout the amygdala, cortex, hippocampus, nucleus accumbens, and raphe (Table 1). 5-Hydroxy-indoleacetic acid (5-HIAA)/5-HT ratios were measured as a marker for turnover, and no significant differences between mutants and WT were found in the amygdala, cortex, hippocampus, nucleus accumbens, and raphe (Table 1). This suggests that baseline alterations in behavior and neurogenesis in $\mathrm{CREB}^{\alpha \Delta}$ mice are not attributable to changes in serotonin or its turnover. Stimulated serotonin release was also equivalent in $\mathrm{WT}$ and $\mathrm{CREB}^{\alpha \Delta}$ mutant mice (supplemental Fig. 2, available at www.jneurosci.org as supplemental material), again demonstrating that CREB deficiency throughout development does not impact serotonin metabolism. The efficacy of PCPA treatment in these experiments was verified by a $72-90 \%$ reduction in serotonin levels in comparison with saline-treated animals: $F_{(1,29)}=213.09, p<0.0001 ; F_{(1,29)}=$ $217.51, p<0.0001 ; F_{(1,29)}=148.14, p<0.0001 ; F_{(1,27)}=24.54$, $p<0.0001 ; F_{(1,28)}=122.10, p<0.0001$, measured in the amygdala, cortex, hippocampus, nucleus accumbens, and raphe, respectively. The magnitude of PCPA depletion in discrete brain regions was equivalent across genotypes.

\section{WT and CREB ${ }^{\alpha \Delta}$ mutant mice respond to chronic} antidepressant treatment in the NIH paradigm

The NIH paradigm has been reported to be sensitive to chronic, but not acute, antidepressant treatment. Therefore, we used this paradigm to determine whether $\mathrm{CREB}^{\alpha \Delta}$ mutant mice respond to chronic AD treatment. As shown in Figure 5, DMI significantly reduced the latency to consume the food in a novel environment for both WT and CREB ${ }^{\alpha \Delta}$ mutant mice. There was a main effect of genotype with mutants showing overall higher latencies $\left(F_{(1,34)}\right.$ $=4.78 ; p=0.0358)$, an effect of treatment with treated mice showing lower latencies $\left(F_{(1,34)}=11.11 ; p=0.0021\right)$, and no genotype by treatment interaction $\left(F_{(1,34)}=1.35 ; p=0.2541\right)$. Two-way ANOVA with repeated measures revealed a main effect of condition with longer latencies for the novel compared with home conditions $\left(F_{(2,68)}=58.12 ; p<0.0001\right)$, a genotype by condition interaction with higher latencies for $\mathrm{CREB}^{\alpha \Delta}$ mutant mice compared with WT in the novel condition $\left(F_{(2,68)}=4.68\right.$; $p=0.0125)$, a treatment by condition interaction with lower latencies for DMI-treated mice in the novel condition $\left(F_{(2,68)}=\right.$ $12.21 ; p<0.000)$, but no three-way interaction $\left(F_{(2,68)}=1.42\right.$; $p=0.2476$ ). In addition, $\mathrm{CREB}^{\alpha \Delta}$ mutant mice had generally increased latencies in the novel environment compared with WT mice, consistent with the anxiogenic phenotype observed in the zero maze (Fig. 4). Of the 40 mice tested, 2 were eliminated from 
Table 1. Serotonin tissue content (picograms per microliter) and turnover (5-HIAA/5-HT)

\begin{tabular}{|c|c|c|c|c|c|c|c|c|}
\hline \multirow[b]{2}{*}{ Brain region } & \multicolumn{2}{|l|}{ WT-saline } & \multicolumn{2}{|c|}{ CREB $^{\alpha \Delta}$-saline } & \multicolumn{2}{|l|}{ WT-PCPA } & \multicolumn{2}{|c|}{$\mathrm{CREB}^{\alpha \Delta_{-}} \mathrm{PCPA}$} \\
\hline & Levels & Turnover & Levels & Turnover & Levels & Turnover & Levels & Turnover \\
\hline Amygdala & $367 \pm 22$ & $0.52 \pm 0.03$ & $338 \pm 24$ & $0.53 \pm 0.03$ & $62 \pm 4$ & $0.24 \pm 0.01$ & $57 \pm 6$ & $0.25 \pm 0.02$ \\
\hline Frontal cortex & $223 \pm 6$ & $0.53 \pm 0.02$ & $196 \pm 11$ & $0.52 \pm 0.02$ & $54 \pm 21$ & $0.33 \pm 0.13$ & $34 \pm 8$ & $0.19 \pm 0.03$ \\
\hline Hippocampus & $653 \pm 59$ & $1.07 \pm 0.05$ & $690 \pm 59$ & $1.14 \pm 0.08$ & $82 \pm 7$ & $0.36 \pm 0.03$ & $64 \pm 9$ & $0.32 \pm 0.05$ \\
\hline Nucleus accumbens & $195 \pm 11$ & $0.52 \pm 0.06$ & $198 \pm 35$ & $0.42 \pm 0.03$ & $41 \pm 7$ & $0.23 \pm 0.04$ & $37 \pm 9$ & $0.18 \pm 0.04$ \\
\hline Brainstem & $457 \pm 36$ & $1.04 \pm 0.09$ & $440 \pm 38$ & $1.02 \pm 0.07$ & $128 \pm 22$ & $0.92 \pm 0.05$ & $124 \pm 16$ & $0.69 \pm 0.07$ \\
\hline
\end{tabular}

Mice ( $n=8-9$ per group) were killed $18 \mathrm{~h}$ after the last injection of PCPA. Brains were microdissected and HPLC coupled with EC was used to assay the filtered supernatant for serotonin content. Baseline serotonin levels, turnover, and depletion in CREB ${ }^{\alpha \Delta}$ mutant mice did not differ from that of WT mice throughout the amygdala, cortex, hippocampus, nucleus accumbens, and raphe.

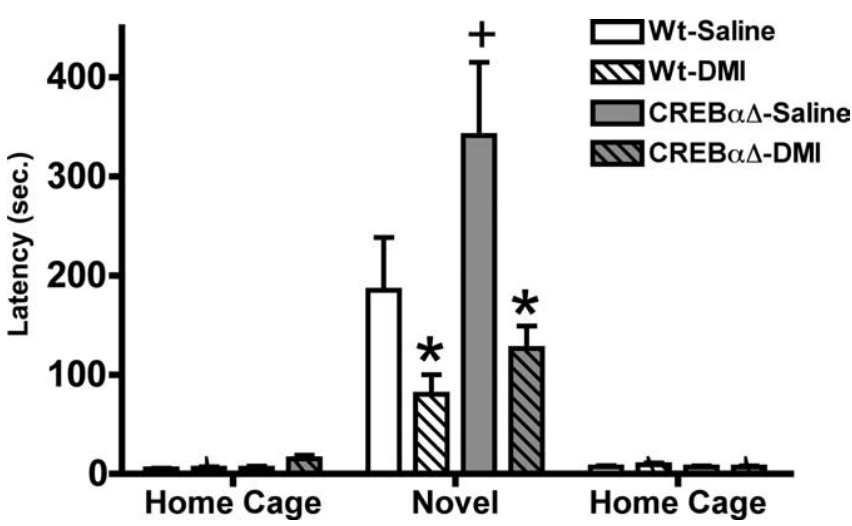

Figure 5. Chronic DMI treatment decreased the latency to consume peanut butter chips in the novel environment in both WT and CREB ${ }^{\alpha \Delta}$ mutant mice. Mean latencies to consume the highly palatable food in the home and novel environment are shown. Mice were treated with DMI $(12.5 \mathrm{mg} / \mathrm{kg})$ for $25 \mathrm{~d}$ before testing. There was a decreased latency in DMl relative to saline-treated animals $\left({ }^{*} p<0.004\right)$. There was an overall increased latency in mutant relative to WT animals $\left({ }^{+} p<0.04\right)(n=9-10)$. Error bars indicate SEM.

analysis for having latency scores less than or greater than 2 SDs from the mean.

\section{$\mathrm{CREB}^{\alpha \Delta}$ mutant mice respond to acute antidepressant treatment in the $\mathrm{NIH}$ paradigm}

To control for the acute effects of $\mathrm{AD}$ in this paradigm, mice were trained to consume a highly palatable food, and then injected on the three testing days with $12.5 \mathrm{mg} / \mathrm{kg}$ DMI or saline in the morning (9:00-10:00 A.M.) and afternoon (4:00-5:00 P.M.). Testing occurred at exactly the same time point after DMI as described for the chronic experiment. As expected, acute DMI had no effect on altering latency to consume food in a novel environment in WT mice. In contrast, the time required by $\mathrm{CREB}^{\alpha \Delta}$ mutant mice to investigate and consume the food was significantly reduced (Fig. 6). The overall main effects of genetic group and treatment group were replicated, with mutants showing overall higher latencies $\left(F_{(1,24)}=4.90 ; p=0.0366\right)$ and treated mice showing lower latencies $\left(F_{(1,24)}=9.40 ; p=0.0053\right)$, but this time the genotype by treatment interaction was also significant $\left(F_{(1,24)}=\right.$ $6.18 ; p=0.0202)$. There was no treatment effect in the WT mice. Two-way ANOVA with repeated measures showed a main effect of condition $\left(F_{(2,48)}=89.98 ; p<0.0001\right)$ with longer latencies in the novel condition, a genetic group by condition interaction $\left(F_{(2,48)}=4.64 ; p=0.0143\right)$ with longer latencies in the CREB ${ }^{\alpha \Delta}$ mutant mice for the novel condition, a treatment by condition interaction $\left(F_{(2,48)}=9.86 ; p=0.0003\right)$ with longer latencies in untreated than treated mice, and these were accounted for by a three-way interaction $\left(F_{(2,48)}=6.86 ; p=0.0024\right)$. The three-way interaction indicates an effect of acute treatment in the $\mathrm{CREB}^{\alpha \Delta}$ mutant mice relative to the absence of treatment effects in the WT mice. As seen previously (Fig. 5), saline-treated CREB ${ }^{\alpha \Delta}$ mutant

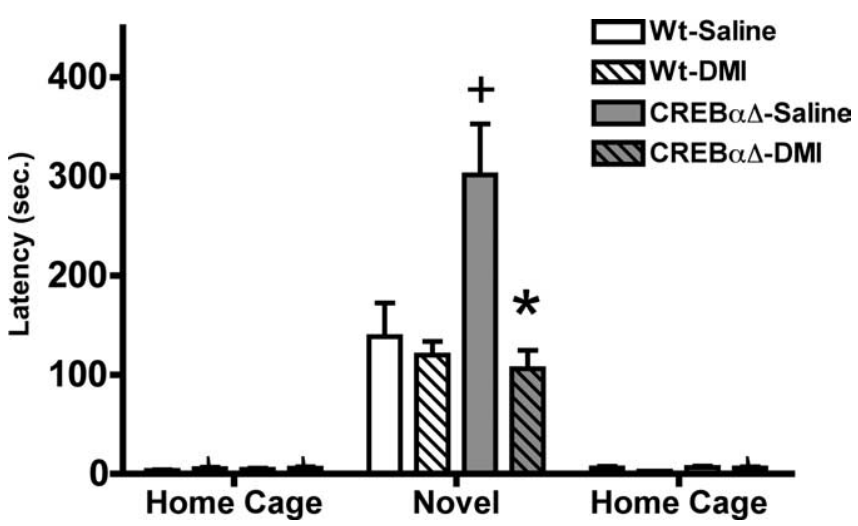

Figure 6. $\quad \mathrm{CREB}^{\alpha \Delta}$ mutant mice demonstrated a significant decrease in latency in response to acute DMI treatment, whereas there was no effect of treatment in the WT mice. Mean latencies to consume the highly palatable food in the home and novel environment are shown. Mice ( $n=9-10$ per group) received a dose of DMI $(12.5 \mathrm{mg} / \mathrm{kg})$ in the morning and evening of each of the $3 \mathrm{~d}$ of testing. A total of three doses of DMI was received before exposure to the novel environment. There was a decreased latency in DMI relative to saline-treated CREB ${ }^{\alpha \Delta}$ mutant mice $\left({ }^{*} p<0.01\right)$. There was also an increased latency in mutant relative to WT animals $\left({ }^{+} p<\right.$ $0.04)(n=7)$. Error bars indicate SEM.

mice demonstrated a significant increase in latency to approach the food and eat over WT mice. Of the 33 mice tested, 5 were eliminated from analysis for having latency scores less than or greater than 2 SDs from the mean, or for failing to reach baseline latency.

Increased baseline anxiety in the elevated zero maze is not reversed in the $\mathrm{CREB}^{\alpha \Delta}$ mutant mice by acute antidepressant treatment

To determine whether DMI had an anxiolytic-like effect in the $\mathrm{CREB}^{\alpha \Delta}$ mutant mice, we tested this compound in the elevated zero maze in WT and CREB ${ }^{\alpha \Delta}$ mutant mice. $\mathrm{CREB}^{\alpha \Delta}$ mutant mice spent significantly less time in the open arm relative to WT mice, reflective of an anxiety-like phenotype. However, this behavior was not mitigated by acute treatment with DMI (Fig. 7A). Two-way ANOVA revealed a main effect of genotype $\left(F_{(1,34)}=\right.$ $20.71 ; p<0.0001)$ on time spent in the open arm. Neither treatment nor genotype by treatment interaction approached significance on this parameter. In regard to ethologically relevant parameters and latency to enter the open arm (Fig. $7 B, C$ ), two-way ANOVAs demonstrated a significant effect of genotype on stretch-attend-posture $\left(F_{(1,34)}=5.93 ; p=0.02\right)$, head dips $\left(F_{(1,34)}=10.904 ; p=0.0023\right)$, and latency $\left(F_{(1,34)}=4.237 ; p=\right.$ $0.0473)$, but not on rearing $\left(F_{(1,34)}=0.026 ; p>0.05\right)$. There was no significant effect of treatment or genotype by treatment interactions on any of these parameters, including head dip, SAP, latency, or rearing. Thus, the acute effect of DMI in CREB ${ }^{\alpha \Delta}$ mutant mice is specific to an antidepressant effect in these mice. 
A
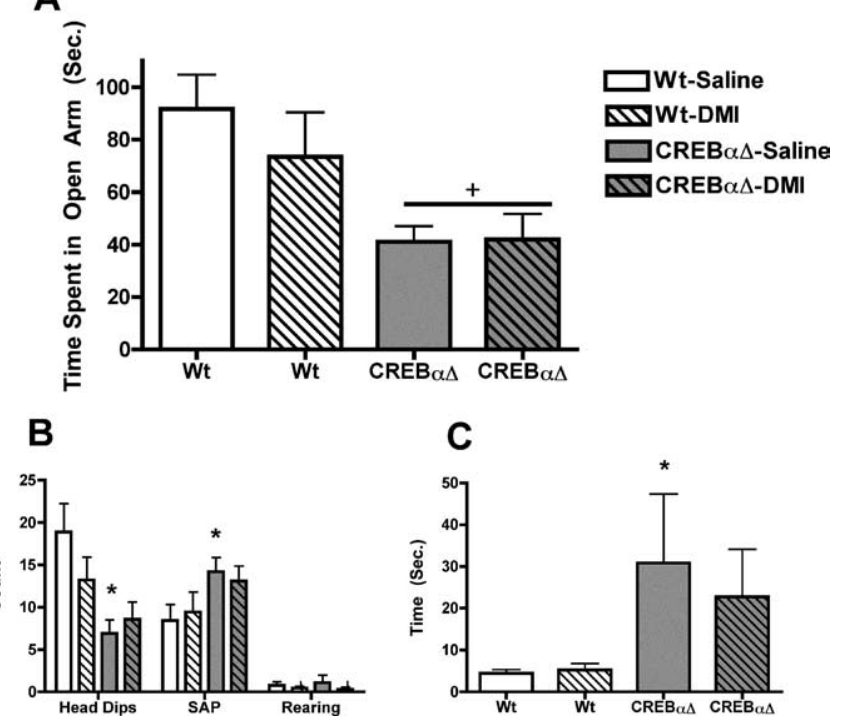

Figure 7. $\boldsymbol{A}, \mathrm{CREB}^{\alpha \Delta}$ mutant mice showed significantly reduced time spent in the open arm relative to WT ( ${ }^{+} p<0.0001$ ) in the elevated zero maze. This reduction was not affected by acute treatment with DMI. Mice ( $n=9-10$ per group) received a total of three doses of DMI $(12.5 \mathrm{mg} / \mathrm{kg}$ ) before testing, with the same schedule used in the NIH. $\boldsymbol{B}$, In regard to ethologically relevant parameters, there is a significant effect of genotype on stretch-attend-posture, and head dips ( ${ }^{*} p<0.05$ ), but not on rearing. C, CREB ${ }^{\alpha \Delta}$ mutant mice demonstrated an increased latency to enter the open arm $\left({ }^{+} p<0.05\right)$. Error bars indicate SEM.

\section{Discussion}

The notion that reduced hippocampal neurogenesis is involved in the pathophysiology of depression has gained traction in recent years (Dranovsky and Hen, 2006; Duman and Monteggia, 2006). AD treatment is thought to ameliorate the symptoms of depression by reversing this process. However, the connection between neurogenesis, its molecular underpinnings, and behavioral consequences are mostly correlative. The FST and the TST are commonly used to assess antidepressant effects of drugs and, more recently, depressive phenotypes in mice (Cryan et al., 2002). CREB ${ }^{\alpha \Delta}$ mutant mice demonstrated decreased immobility in both of these paradigms, which was further reduced by ADs (Conti et al., 2002), suggesting an "antidepressant state" that is still sensitive to drug treatment. Changes in homecage motor activity or swimming behavior were not found (Walters and Blendy, 2001; Graves et al., 2002), and therefore do not account for these findings. To gather information on possible biological substrates responsible for the antidepressant phenotype of $\mathrm{CREB}^{\alpha \Delta}$ mutant mice, we examined neurogenesis, a parameter altered by chronic AD treatment.

Our data demonstrate that constitutive reduction in CREB protein enhances BrdU-labeled cell proliferation. Furthermore, the majority of these cells mature into neurons, indicating that CREB-deficient mice have increased proliferation and neurogenesis, comparable with levels observed in WT mice receiving chronic AD treatment (Malberg et al., 2000). However, chronic treatment with DMI did not further increase hippocampal neurogenesis in CREB-deficient mice. This lack of an additional DMI-induced increase in neurogenesis in the CREB mutant mice may be attributable to inherent proliferative limits of the hippocampus. In previous rat studies, treatment with fluoxetine increased the number of BrdU-labeled cells by $20-40 \%$, whereas electroconvulsive seizure caused a $\sim 50 \%$ increase (Malberg et al., 2000; Warner-Schmidt and Duman, 2007). Because CREB ${ }^{\alpha \Delta}$ mutant mice demonstrate an $\sim 52 \%$ increase in BrdU-positive cells compared with WT mice, it is possible that the hippocampus has reached the upper limits of its neurogenic capacity. Indeed, in another mouse model showing 20\% elevation in baseline levels of hippocampal neurogenesis, chronic treatment with DMI and citalopram failed to further increase neurogenesis (Morcuende et al., 2003).

Our finding of increased levels of hippocampal neurogenesis in the CREB-deficient mice (Fig. 1) differs from the report of decreased levels in a transgenic mouse expressing dominantnegative CREB (mCREB) (Nakagawa et al., 2002a). However by binding to CRE sequences in DNA, mCREB may target genes that are not normally regulated by CREB (Blendy, 2006), thereby altering neurogenesis through other mechanisms. CREB manipulations in other mouse models, and viral vector-mediated gene overexpression, have led to behavioral changes in depressionrelated behavioral paradigms as well. Acute overexpression of CREB in the nucleus accumbens of rats leads to a pro-depressant response in the FST, and a decrease of CREB mediated by expression of a dominant-negative form of the protein in rats leads to an antidepressant-like effect (Pliakas et al., 2001), with similar effects found in the learned helplessness paradigm in mice and rats (Newton et al., 2002). However, acute overexpression of CREB in the hippocampus leads to an antidepressant effect in the FST (Chen et al., 2001). To date, neither levels of neurogenesis nor behavior in paradigms that are sensitive to chronic AD treatment have been evaluated in these models.

To investigate a more causal relationship between neurogenesis, behavior, and CREB, we depleted mice of serotonin with PCPA. Serotonin is thought to play a role in neurogenesis (Gaspar et al., 2003), and previous studies have reported either no change or a decrease in proliferation in rats treated with PCPA (Brezun and Daszuta, 1999, 2000; Banasr et al., 2001; Huang and Herbert, 2005; Jha et al., 2006). Serotonin has been implicated in both the pathophysiology and treatment of depression. Therefore, we wanted to examine the role of serotonin in maintaining cell proliferation and antidepressant behavior in mice that demonstrate an antidepressant-like phenotype and increased levels of neurogenesis. We found that serotonin depletion with PCPA reversed the antidepressant phenotype of $\mathrm{CREB}^{\alpha \Delta}$ mutant mice on both a cellular (Fig. 2) and behavioral (Fig. 3) level, whereas it had no effect on WT mice. Our data support previous findings that PCPA depletion does not have an effect on immobility in WT mice in the TST (O'Leary et al., 2007). Of interest, serotonin levels and turnover did not differ between WT and CREB ${ }^{\alpha \Delta}$ mutant mice (Table 1) and stimulated release of serotonin was also consistent between the two groups (supplemental Fig. 2, available at www.jneurosci.org as supplemental material). However, the serotonergic tone in $\mathrm{CREB}^{\alpha \Delta}$ mutant mice, although not different in magnitude, provides a critical stimulus that causes mice to behave at baseline as though they have undergone chronic AD treatment. Additional studies are warranted to investigate the nature of this complex interaction.

In addition to an antidepressant-like phenotype, $\mathrm{CREB}^{\alpha \Delta}$ mutant mice demonstrate increased levels of anxiety (Graves et al., 2002; Hebda-Bauer et al., 2004). This anxiety phenotype is also evident in the NIH paradigm with $\mathrm{CREB} \alpha \Delta$ mutant mice showing increased latency to feed in a novel environment (Figs. 5, 6). Serotonin depletion does not reverse the anxiogenic-like phenotype in the elevated zero maze (Fig. 4), further emphasizing a specific correlation between the antidepressant phenotype and neurogenesis. Whether PCPA treatment reduces the latency to feed in a novel environment in $\mathrm{CREB}^{\alpha \Delta}$ mutant remains to be seen. Unfortunately, serotonin depletion produces an anxiolytic, 
or decreased hyponeophagia effect in the NIH test in rat (Bechtholt et al., 2007), making it difficult to interpret baseline effects in $\mathrm{CREB}^{\alpha \Delta}$ mutant mice.

Overall, the antidepressant-like phenotype may at first seem at odds with the anxiety phenotype. However, 5- $\mathrm{HT}_{1 \mathrm{~A}}$ knock-out mice also demonstrate an antidepressant phenotype in combination with an increased level of anxiety (Heisler et al., 1998; Parks et al., 1998; Ramboz et al., 1998), suggesting that endophenotypes related to comorbid neuropsychiatric disorders may be uncoupled in animal models.

To date, the significance of CREB in mediating any behaviors associated with chronic $\mathrm{AD}$ treatment have not been investigated in part because of the lack of well validated behavioral paradigms designed to evaluate chronic AD effects. Therefore, to examine the functional significance of increased neurogenesis as well as gain additional insight into possible behavioral implications of this alteration, we tested the $\mathrm{CREB}^{\alpha \Delta}$ mutant mice in the NIH paradigm. In this paradigm, exposure to a novel environment elicits an increased latency to consume a highly palatable food. This increase in latency is reversed by chronic, but not shortterm, AD treatment (Merali et al., 2003), making it a useful model to understand molecular and cellular changes underlying the behavioral response to chronic $\mathrm{AD}$ treatment. It is closely related to the NSF paradigm, with the latter using food deprivation to induce consumption of regular food. A limitation of both the TST and FST is their responsiveness to acute administration of antidepressants. Clinically, weeks of treatment are needed to ameliorate behavioral symptoms, reflecting the need for long-term transcriptional and cellular changes. Using the NIH paradigm, the present data demonstrate that $\mathrm{CREB}^{\alpha \Delta}$ mutant mice respond to acute $\mathrm{AD}$ treatment, an effect not seen in WT mice.

Acute anxiolytic compounds are effective in the NIH paradigm (Merali et al., 2003); thus the acute effect of DMI in the NIH test in $\mathrm{CREB}^{\alpha \Delta}$ mutant mice could be interpreted as an anxiolytic-like response. Caveats associated with constitutive knock-out mouse models range from unexpected compensation, effects on other gene products throughout development, and altered endocrine and neuronal feedback. These types of alterations in the $\mathrm{CREB}^{\alpha \Delta}$ mutant mice could result in a modification of pharmacological profiles of classic AD. To determine whether DMI is exerting anxiolytic effects in $\mathrm{CREB}^{\alpha \Delta}$ mutant mice, we examined its effects on WT and $\mathrm{CREB}^{\alpha \Delta}$ mutant mice in a second test for anxiety, the elevated zero maze. Few studies have examined the response to acute or chronic AD treatment in the elevated plus and elevated zero maze and results have been highly variable. Depending on the test used and the $\mathrm{AD}$ administered, many studies have reported no effect or an anxiogenic effect (Borsini et al., 2002). Our results replicate the lack of efficacy of acute DMI treatment in the elevated zero maze in WT mice. Moreover, DMI is not effective in reducing anxiety in $\mathrm{CREB}^{\alpha \Delta}$ mutant mice, suggesting the acute action of DMI in the NIH test may be more related to the antidepressant responsive aspects of this paradigm.

$\mathrm{AD}$ effects in the NIH paradigm may require cellular changes in response to AD treatment as well. In the NSF paradigm, it has been shown that neurogenesis is necessary for a behavioral response to AD treatment (Santarelli et al., 2003). Thus, the increased levels of neurogenesis in $\mathrm{CREB}^{\alpha \Delta}$ mutant mice may provide a mechanism for the rapid onset of response to treatment effects in these mice. Without the usual requirement of increasing neurogenesis, AD drugs may exert behavioral effects more rapidly in an animal that has been "primed" to respond to these compounds. Although CREB activation after AD treatment may serve to initiate mechanisms that underlie the lengthy time course needed to achieve the behavioral effect in WT mice, under conditions in which CREB is constitutively deleted these mechanisms are already engaged. Our findings have potential clinical implications, because the delayed onset of a behavioral response to $\mathrm{AD}$ treatment poses a challenge. Identification of mechanisms through which CREB influences neurogenesis and the behavioral response to $\mathrm{AD}$ treatment may identify new targets for fasteracting therapies for depression.

\section{References}

Banasr M, Hery M, Brezun JM, Daszuta A (2001) Serotonin mediates oestrogen stimulation of cell proliferation in the adult dentate gyrus. Eur J Neurosci 14:1417-1424.

Bechtholt AJ, Hill TE, Lucki I (2007) Anxiolytic effect of serotonin depletion in the novelty-induced hypophagia test. Psychopharmacology (Berl) 190:531-540.

Blendy JA (2006) The role of CREB in depression and antidepressant treatment. Biol Psychiatry 59:1144-1150.

Blendy JA, Kaestner KH, Schmid W, Gass P, Schutz G (1996) Targeting of the CREB gene leads to up-regulation of a novel CREB mRNA isoform. EMBO J 15:1098-1106.

Blom JM, Tascedda F, Carra S, Ferraguti C, Barden N, Brunello N (2002) Altered regulation of CREB by chronic antidepressant administration in the brain of transgenic mice with impaired glucocorticoid receptor function. Neuropsychopharmacology 26:605-614.

Borsini F, Podhorna J, Marazziti D (2002) Do animal models of anxiety predict anxiolytic-like effects of antidepressants? Psychopharmacology (Berl) 163:121-141.

Brezun JM, Daszuta A (1999) Depletion in serotonin decreases neurogenesis in the dentate gyrus and the subventricular zone of adult rats. Neuroscience 89:999-1002.

Brezun JM, Daszuta A (2000) Serotonergic reinnervation reverses lesioninduced decreases in PSA-NCAM labeling and proliferation of hippocampal cells in adult rats. Hippocampus 10:37-46.

Cameron HA, McKay RD (2001) Adult neurogenesis produces a large pool of new granule cells in the dentate gyrus. J Comp Neurol 435:406-417.

Carlezon Jr WA, Duman RS, Nestler EJ (2005) The many faces of CREB. Trends Neurosci 28:436-445.

Chen AC, Shirayama Y, Shin KH, Neve RL, Duman RS (2001) Expression of the cAMP response element binding protein (CREB) in hippocampus produces an antidepressant effect. Biol Psychiatry 49:753-762.

Conti AC, Cryan JF, Dalvi A, Lucki I, Blendy JA (2002) cAMP response element-binding protein is essential for the upregulation of brain-derived neurotrophic factor transcription, but not the behavioral or endocrine responses to antidepressant drugs. J Neurosci 22:3262-3268.

Cryan JF, Markou A, Lucki I (2002) Assessing antidepressant activity in rodents: recent developments and future needs. Trends Pharmacol Sci 23:238-245.

Cryan JF, Mombereau C, Vassout A (2005) The tail suspension test as a model for assessing antidepressant activity: review of pharmacological and genetic studies in mice. Neurosci Biobehav Rev 29:571-625.

Czeh B, Michaelis T, Watanabe T, Frahm J, de Biurrun G, van Kampen M, Bartolomucci A, Fuchs E (2001) Stress-induced changes in cerebral metabolites, hippocampal volume, and cell proliferation are prevented by antidepressant treatment with tianeptine. Proc Natl Acad Sci USA 98:12796-12801.

Dranovsky A, Hen R (2006) Hippocampal neurogenesis: regulation by stress and antidepressants. Biol Psychiatry 59:1136-1143.

Dulawa SC, Hen R (2005) Recent advances in animal models of chronic antidepressant effects: the novelty-induced hypophagia test. Neurosci Biobehav Rev 29:771-783.

Duman RS, Monteggia LM (2006) A neurotrophic model for stress-related mood disorders. Biol Psychiatry 59:1116-1127.

Eisch AJ (2002) Adult neurogenesis: implications for psychiatry. Prog Brain Res 138:315-342.

Frazer A, Benmansour S (2002) Delayed pharmacological effects of antidepressants. Mol Psychiatry 7 [Suppl 1]:S23-S28.

Gaspar P, Cases O, Maroteaux L (2003) The developmental role of serotonin: news from mouse molecular genetics. Nat Rev Neurosci 4:1002-1012. 
Gould E, Beylin A, Tanapat P, Reeves A, Shors TJ (1999) Learning enhances adult neurogenesis in the hippocampal formation. Nat Neurosci 2:260-265

Graves L, Dalvi A, Lucki I, Blendy JA, Abel T (2002) Behavioral analysis of CREB alphadelta mutation on a B6/129 F1 hybrid background. Hippocampus 12:18-26.

Hebda-Bauer EK, Watson SJ, Akil H (2004) CREB deficient mice show inhibition and low activity in novel environments without changes in stress reactivity. Eur J Neurosci 20:503-513.

Heisler LK, Chu HM, Brennan TJ, Danao JA, Bajwa P, Parsons LH, Tecott LH (1998) Elevated anxiety and antidepressant-like responses in serotonin 5-HT1A receptor mutant mice. Proc Natl Acad Sci USA 95:15049-15054.

Huang GJ, Herbert J (2005) Serotonin modulates the suppressive effects of corticosterone on proliferating progenitor cells in the dentate gyrus of the hippocampus in the adult rat. Neuropsychopharmacology 30:231-241.

Hummler E, Cole TJ, Blendy JA, Ganss R, Aguzzi A, Schmid W, Beermann F, Schutz G (1994) Targeted mutation of the CREB gene: compensation within the CREB/ATF family of transcription factors. Proc Natl Acad Sci USA 91:5647-5651.

Jha S, Rajendran R, Davda J, Vaidya VA (2006) Selective serotonin depletion does not regulate hippocampal neurogenesis in the adult rat brain: differential effects of $p$-chlorophenylalanine and 5,7-dihydroxytryptamine. Brain Res 1075:48-59.

Jones MD, Lucki I (2005) Sex differences in the regulation of serotonergic transmission and behavior in 5-HT receptor knockout mice. Neuropsychopharmacology 30:1039-1047.

Kodama M, Fujioka T, Duman RS (2004) Chronic olanzapine or fluoxetine administration increases cell proliferation in hippocampus and prefrontal cortex of adult rat. Biol Psychiatry 56:570-580.

Lucki I (2001) A prescription to resist proscriptions for murine models of depression. Psychopharmacology (Berl) 153:395-398.

Magarinos AM, McEwen BS, Flugge G, Fuchs E (1996) Chronic psychosocial stress causes apical dendritic atrophy of hippocampal CA3 pyramidal neurons in subordinate tree shrews. J Neurosci 16:3534-3540.

Malberg JE, Eisch AJ, Nestler EJ, Duman RS (2000) Chronic antidepressant treatment increases neurogenesis in adult rat hippocampus. J Neurosci 20:9104-9110.

Manev H, Uz T, Smalheiser NR, Manev R (2001) Antidepressants alter cell proliferation in the adult brain in vivo and in neural cultures in vitro. Eur J Pharmacol 411:67-70.

McEwen BS (1999) Stress and hippocampal plasticity. Annu Rev Neurosci 22:105-122.

Merali Z, Levac C, Anisman H (2003) Validation of a simple, ethologically relevant paradigm for assessing anxiety in mice. Biol Psychiatry 54:552-565.

Morcuende S, Gadd CA, Peters M, Moss A, Harris EA, Sheasby A, Fisher AS, De Felipe C, Mantyh PW, Rupniak NM, Giese KP, Hunt SP (2003) Increased neurogenesis and brain-derived neurotrophic factor in neurokinin-1 receptor gene knockout mice. Eur J Neurosci 18:1828-1836.

Nakagawa S, Kim JE, Lee R, Malberg JE, Chen J, Steffen C, Zhang YJ, Nestler EJ, Duman RS (2002a) Regulation of neurogenesis in adult mouse hippocampus by cAMP and the cAMP response element-binding protein. J Neurosci 22:3673-3682.

Nakagawa S, Kim JE, Lee R, Chen J, Fujioka T, Malberg J, Tsuji S, Duman RS (2002b) Localization of phosphorylated cAMP response elementbinding protein in immature neurons of adult hippocampus. J Neurosci 22:9868-9876.

Nestler EJ, Barrot M, DiLeone RJ, Eisch AJ, Gold SJ, Monteggia LM (2002) Neurobiology of depression. Neuron 34:13-25.

Newton SS, Thome J, Wallace TL, Shirayama Y, Schlesinger L, Sakai N, Chen
J, Neve R, Nestler EJ, Duman RS (2002) Inhibition of cAMP response element-binding protein or dynorphin in the nucleus accumbens produces an antidepressant-like effect. J Neurosci 22:10883-10890.

Nibuya M, Nestler EJ, Duman RS (1996) Chronic antidepressant administration increases the expression of cAMP response element binding protein (CREB) in rat hippocampus. J Neurosci 16:2365-2372.

O'Leary OF, Bechtholt AJ, Crowley JJ, Hill TE, Page ME, Lucki I (2007) Depletion of serotonin and catecholamines block the acute behavioral response to different classes of antidepressant drugs in the mouse tail suspension test. Psychopharmacology (Berl) 192:357-371.

Palmer TD, Willhoite AR, Gage FH (2000) Vascular niche for adult hippocampal neurogenesis. J Comp Neurol 425:479-494.

Parks CL, Robinson PS, Sibille E, Shenk T, Toth M (1998) Increased anxiety of mice lacking the serotonin 1A receptor. Proc Natl Acad Sci USA 95:10734-10739.

Pliakas AM, Carlson RR, Neve RL, Konradi C, Nestler EJ, Carlezon Jr WA (2001) Altered responsiveness to cocaine and increased immobility in the forced swim test associated with elevated cAMP response elementbinding protein expression in nucleus accumbens. J Neurosci 21:7397-7403.

Ramboz S, Oosting R, Amara DA, Kung HF, Blier P, Mendelsohn M, Mann JJ, Brunner D, Hen R (1998) Serotonin receptor 1A knockout: an animal model of anxiety-related disorder. Proc Natl Acad Sci USA 95:14476-14481

Sairanen M, Lucas G, Ernfors P, Castren M, Castren E (2005) Brain-derived neurotrophic factor and antidepressant drugs have different but coordinated effects on neuronal turnover, proliferation, and survival in the adult dentate gyrus. J Neurosci 25:1089-1094.

Santarelli L, Saxe M, Gross C, Surget A, Battaglia F, Dulawa S, Weisstaub N, Lee J, Duman R, Arancio O, Belzung C, Hen R (2003) Requirement of hippocampal neurogenesis for the behavioral effects of antidepressants. Science 301:805-809.

Sheline YI (1996) Hippocampal atrophy in major depression: a result of depression-induced neurotoxicity? Mol Psychiatry 1:298-299.

Sheline YI, Gado MH, Kraemer HC (2003) Untreated depression and hippocampal volume loss. Am J Psychiatry 160:1516-1518.

Stein-Behrens B, Mattson MP, Chang I, Yeh M, Sapolsky R (1994) Stress exacerbates neuron loss and cytoskeletal pathology in the hippocampus. J Neurosci 14:5373-5380.

Thome J, Sakai N, Shin K, Steffen C, Zhang YJ, Impey S, Storm D, Duman RS (2000) cAMP response element-mediated gene transcription is upregulated by chronic antidepressant treatment. J Neurosci 20:4030-4036.

Tiraboschi E, Tardito D, Kasahara J, Moraschi S, Pruneri P, Gennarelli M, Racagni G, Popoli M (2004) Selective phosphorylation of nuclear CREB by fluoxetine is linked to activation of CaM kinase IV and MAP kinase cascades. Neuropsychopharmacology 29:1831-1840.

Walters CL, Blendy JA (2001) Different requirements for cAMP response element binding protein in positive and negative reinforcing properties of drugs of abuse. J Neurosci 21:9438-9444.

Warner-Schmidt JL, Duman RS (2007) VEGF is an essential mediator of the neurogenic and behavioral actions of antidepressants. Proc Natl Acad Sci USA 104:4647-4652.

Watanabe Y, Gould E, McEwen BS (1992) Stress induces atrophy of apical dendrites of hippocampal CA3 pyramidal neurons. Brain Res 588:341-345.

Wong ML, Licinio J (2001) Research and treatment approaches to depression. Nat Rev Neurosci 2:343-351.

Young LT, Bakish D, Beaulieu S (2002) The neurobiology of treatment response to antidepressants and mood stabilizing medications. J Psychiatry Neurosci 27:260-265. 